\title{
Assessing the effect of the taxation of small business on the socio-economic development of the country
}

\author{
Trukhanenko Ann \\ Tomsk Polytechnic University \\ TPU \\ Tomsk, Russia \\ trukhanneko@sibmail.com
}

\author{
Artcer Tatiana \\ Tomsk Polytechnic University \\ TPU \\ Tomsk, Russia \\ atvtpu@sibmail.com
}

\begin{abstract}
The author of article the influence of the taxation of small business on the socio-economic development of the country. A comparison is made of the Russian Federation with the developed countries the development of small business policy.
\end{abstract}

Keywords - taxes, tax burden, tax policy, small and medium business

In any state, having the specificity of tasks, an important role is played by the tax system in the mobilization of financial resources of society. At the current stage of development and overcoming the negative consequences of the transitional period, they are offered to overcome due to the formation of business, in which the development opportunities of self-realization of certain sectors of society, in order to achieve preferences, as well as through the tax system namely, strengthening and stimulating social tax functions. For the optimization of the tax system, in the conditions in which it is at the moment, you need to thoroughly study the Russian experience in conducting economic reforms, as well as detail to use theoretical and practical aspects of fiscal science.

The increase in income tax and contributions to social insurance funds has occurred in almost all more or less developed countries. Taxes can be divided into direct and indirect, but it turns out that are subject to both income and expenses. The boundaries are conditional, because it all depends on the possibility of shifting the tax data. Considering the question, it can be noted about the structure of the tax system change, because of the progressive effects of taxation, inflation and economic growth has a greater impact on the revenue part of the direct taxes rather than indirect.

The main problem of the state is that it is necessary to find ways of how to increase the removal of national income by means of tax exemptions. If we compare the rates for certain taxes and charges, it is impossible to determine the severity of the tax burden in different countries, and you can not accurately assess the impact of the tax system on financial and economic power of the population.

Development of small and medium-sized businesses in economically developed countries is rapidly, the authorities attach great importance to such enterprises and provide them with full support in the development, develop special programs to support and provide a wide range of benefits. In many developed countries, small and medium business plays a very important economic and social role and is a middle class, which serves as the basis for the stable development of the economy and employs the majority of the population. In these countries, $50-70 \%$ of the GDP is produced by small and medium-sized enterprises.

\section{TAXATION IN THE DEVELOPED COUNTRY}

\section{A. USA}

In the United States of America in the category of small and medium enterprises are business entities with number of employees less than 500 people. All small and medium-sized enterprises in the United States are divided into 3 categories:

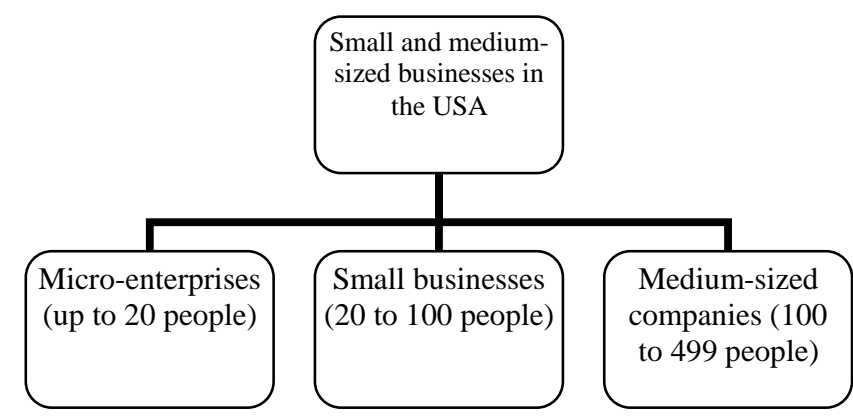

Fig.1. Small and medium sized business in the USA

In addition, separately isolated enterprises that use hired labor, and those where the owner of the company does without involvement of hired personnel.

Currently, there are about 7 million. Enterprises with number of employees less than 500 people in the US, of which 6 million. Enterprises employing less than 20 people each.

In all states of the country, regional offices of the Administration Small Business Administration (SBA), interact with the Center for the Development of Enterprise (CDE). PCR AMB created together with universities (sometimes with the state administration). SBA provides $50 \%$ funding for CRP, i.e. from the federal budget. The remaining $50 \%$ are covered by the host country of any one of the following sources: own funds of the university, the state budget, private sponsors or patrons. The host country can provide financing and material resources (facilities, equipment, machinery, etc.).

CRP did not receive direct revenue and profit, and activities aimed at achieving results in the form of indirect tax on the 
receipt of small businesses and creating new jobs. Slight PCR revenues obtained from the trainings and seminars for entrepreneurs. These funds are used to pay for the services of teachers and rooms for rent. Attracted by teachers and counselors PIU should definitely have experience of their own business.

The main emphasis on training PIU make public the skills of entrepreneurship and business, finding sources of financing and advisory services to expand existing business.[1]

Table 1 shows the comparative characteristics of small business in Russia and the United States.

TABLE 1

\begin{tabular}{|c|c|c|}
\hline USA & & RUSSIA \\
\hline $50 \%$ & $\begin{array}{l}\text { The share of small business in } \\
\text { GDP }\end{array}$ & $20 \%$ \\
\hline $1 / 15$ citizens & $\begin{array}{c}\text { The number of individual } \\
\text { entrepreneurs }\end{array}$ & $1 / 47$ citizens \\
\hline $24 \%$ & $\begin{array}{l}\text { The share of patents in high- } \\
\text { tech }\end{array}$ & negligible \\
\hline $34 \%$ & The share in exports & $5 \%$ \\
\hline $22 \%$ & $\begin{array}{l}\text { The share of state purchases } \\
\text { from small businesses }\end{array}$ & $6 \%$ \\
\hline $13,30 \%$ & Taxes & $80 \%$ \\
\hline $51 \%$ & $\begin{array}{l}\text { The share of companies } \\
\text { survived } 5 \text { years }\end{array}$ & $\begin{array}{l}\text { less than } \\
3 \%\end{array}$ \\
\hline
\end{tabular}

This table clearly shows that small businesses in the US pays much less taxes than in Russia.

\section{B. Finland}

Or, for example, small and medium business plays an important role in social and economic life of Finland. Of the total number of registered enterprises in the country more than $90 \%$ falls into the category of SMEs. Their total annual turnover is $52 \%$ of the total turnover of all the companies and the share in GDP - 50\%. They employ $50 \%$ of all employees, and annually with their help create $60 \%$ of new jobs. The share of SMEs in Finnish exports is $17 \%$ and is growing at a faster rate than larger companies. Investment in research and development in this category of enterprises is $12 \%$.

Priority support in Finland are SMEs in the field of high technologies. The Government has selected a few basic scientific and technical fields in which Finland can really claim to world leadership: electronics, information technology and telecommunications, chemistry, biotechnology, timber and metal processing, energy, shipbuilding.

Support for small and medium-sized businesses in Finland is carried out at four levels: international (EU), national, regional and local levels.

Of particular importance in the system of support for small and medium-sized enterprises is being implemented in Finland set of measures aimed at creating for them a special favorable treatment in a number of sectors and production areas through the provision of tax, customs and tariff concessions, in particular:

- Tax exemptions granted to promote the development of the construction industry metal industry;

- Tax benefits to ship-owners;

- VAT exemption on export (this also applies to the importation of goods used in the production of export products).

Also it should be noted that there are different rankings of countries on the ease of doing business. Against the background of various regional rankings and corporate research highlights Doing business (Doing Business), ranking compiled jointly by the International Finance Corporation (IFC) and the World Bank (World Bank).[2]

The rating is compiled on the basis of ten indicators of business regulation, taking into account the time and cost to meet government requirements in employer registration of a new enterprise, the enterprise, conducting trade, enforcement of contracts, taxation, and closure. Each indicator has equal weight. It does not take into account variables such as macroeconomic policy, quality of infrastructure, skilled labor force, fluctuations in exchange rates, investor perceptions, security and the level of corruption. Thus, the conditions of the organization and business are considered without regard to the political aspects, only at the level of legislation and regulations. The final ranking of all countries are ranked by ease of doing business with 1 to 189 seats, the first place - the highest. The high position of the country means that its regulatory climate conducive to business. The level is an average-favored country by 10 indicators, each indicator has an equal weight.

TABLE 2

\begin{tabular}{|c|c|c|c|}
\hline Country & Rank & $\begin{array}{c}\text { Business } \\
\text { registration }\end{array}$ & Taxation \\
\hline Singapore & 1 & 10 & 5 \\
\hline New Zealand & 2 & 1 & 22 \\
\hline Denmark & 3 & 29 & 29 \\
\hline South Korea & 4 & 23 & 4 \\
\hline Hong Kong & 5 & 4 & 15 \\
\hline United Kingdom & 6 & 17 & 53 \\
\hline USA & 7 & 49 & 37 \\
\hline Sweden & 8 & 16 & 17 \\
\hline Norway & 9 & 24 & $\ldots$ \\
\hline Finland & 10 & 33 & 47 \\
\hline$\ldots$ & $\ldots$ & $\ldots$ & 104 \\
\hline Russia & 51 & 41 & 160 \\
\hline$\ldots$ & $\ldots$ & $\ldots$ & 174 \\
\hline South Sudan & 187 & 181 & \\
\hline Libya & 188 & 158 & 184 \\
\hline Eritrea & 189 & & \\
\hline
\end{tabular}

Russian Federation over the past year, has improved its position and rose from 112 to 51 in the rankings. In general, Russia has improved the business environment for 7 of the 10 indicators analyzed in the study, and the results were a new report for the country's best ever recorded. 
However, until now not possible to achieve sustainable revenues to the budget, social funds to provide state support for investment and export growth (excluding raw materials). Any decisions made in the field of taxation should be made taking into account the possible social and political consequences. Over the years, the Company established a negative attitude to the tax system and to the overall taxes. After all, the media and the authorities, we can say, formed by long years of "negative" in relation to taxes.

\section{TAX BURDEN IN RUSSIA}

The tax burden in Russia is much higher than in some countries. If we assess the level of taxation of certain factors such as depreciation, wages, profits, it is also possible to note the excess, in comparison with some other countries. Many companies related to the small businesses do not have the desire to acquire fixed assets, as if they do not have to pay property tax. Employers tend not to fully charge wages, and to issue it through the so-called "black cash". All this, in turn, affects the formation of the revenue side of the budget system. A system of tax evasion legally.

Analyzing tax revenues in Russia in comparison with other countries, you can highlight some distinctive features:

- a high proportion of the tax on personal income with the population and the corporate profit tax;

- about $80 \%$ of revenues, which is an overwhelming part of direct taxation, as a rule, from income tax;

- in the income share of high value-added tax (VAT) on goods and services;

- the proportion of revenues to the social funds is very low at the expense of personal income.[3]

\section{The structure of revenues of the consolidated budget of the Russian Federation in January- November 2015}

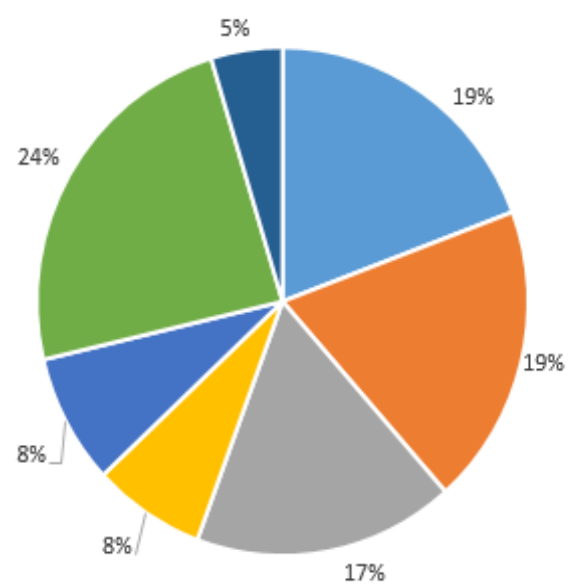

- Tax on profits

- PIT

-VAT

- Excises

- Property taxes

- MET

- Other taxes and fees

Fig. 2. The structure of revenues of the consolidated budget of the Russian Federation
All taxpayers, for example, experienced a sharp increase in the tax burden on the wage fund from 01.01.2011 With this change, the Government has decided to reduce the deficit of the Pension Fund. Analyzing this innovation, we can safely say that the greatest "impact" in percentage terms is made in the public sector (public utilities, education, health). In other words - all the industries where wages are the Greatest share of the costs. According to many analysts, these sectors are the most affected by the crisis. But if we consider the effect of this fiscal tax increases, it can be concluded that it is much lower than expected. The state does not increase the budget revenues of the Pension Fund. If we remember the events of recent years, after the reduction of the tax burden on the wage fund a lot of wages in 2000 brought the so-called "shadow". To date, there is a reverse effect, and in the end the result will be negative.

The Russian tax system is widely used as special tax regimes - in turn, they are one of the main forms of realization of social and stimulating function of taxes. Special tax regimes applicable to individual taxpayers - for example, a simplified version of taxation - i.e. replacement of one tax of many major taxes, which are paid at the general regime of taxation, such as VAT, income tax, property tax organization.

In the calculations the most effective tax rates and payments, it can be concluded that, in general, the tax burden of Russia is approximately $60 \%$, which far exceeds the level in many foreign countries, as well as higher "tax trap", and, as a result, at these rates, the investment for the development of the production is simply not profitable. Lower rates, as the analysis shows, in different countries do not reduce, but rather increase the development of industrial activities in the field of social care services provided by a sufficiently high level of life of citizens. And it's not the allegations, but proven socioeconomic indicators. Of course, it is possible to determine the tax system as a "tax burden".

Tax press in Russia, as in some other countries, is not easy. Of course, the so-called "tax burden" can and should be easier. But it is necessary to pay attention to a lot of important fact: arguing objectively, we can say that many taxpayers do not realize, and many especially do not want to know that all taxes, namely, their rates and the amount of the tax base, and other criteria, and so-called " the tax burden ", are in fact the result of Russian fiscal policy. All tax revenue is primarily determined by the revenue part of the budget, and therefore the size of government spending. The sources from which the state derives income are limited - especially acutely visible in the economic downturn. In these difficult times to help the state comes known and successfully applied and abroad method: changes in the direction of increasing tax rates, the adoption of new taxes, expansion of the objects of taxation, and in addition, expanding the right, but not the responsibilities of local authorities in the manifestation of independence in taxation area.

The impact of taxation on the socio-economic development carried out at various state levels of government. Specific effects can be exerted at the level of a specific tax, but it is necessary to assess the combined impact of taxes. In accordance with the amount of tax actually paid tax theory can be presented as follows: 


$$
\mathrm{f}=\mathrm{SBT} \mathrm{t}^{*} \pm \Delta \mathrm{DTR}
$$

where

$\mathrm{f}$ - the amount of tax actually paid;

SB - the tax base;

$\mathrm{t}$ - nominal tax rate;

TR - the amount of tax relief granted to a taxpayer in accordance with applicable law;

$\Delta \mathrm{D}$ - reduction of the tax debt. Taking the decision to change one of the elements of taxation, the state regulates the amount of the tax exemptions on a specific type of tax. At this level, the relationship established between the tax base and the amount of tax actually paid, i.e. it is a real calculation of the tax rate.[4]

At the micro level the tax burden can be determined:

$$
\mathrm{TB}=(\Sigma \mathrm{N} / \mathrm{FP}) \times 100 \%
$$

where

TB - the tax burden;

$\Sigma \mathrm{N}$ - a set of the taxpayer for the analyzed period (rubles.);

FP - financial performance of the organization for the analyzed period (rubles.).[5]

The problem of positioning of the tax burden in the tax theory is that the specific methods of its calculation, and even more so for the analysis of different categories of taxpayers virtually none.

By virtue of this measure it is abstract and not objectively established in terms of the optimum values for all categories of taxpayers in the business.

\section{CONSLUSION}

Any function of taxes to be implemented, require the control of the state - namely, planning, motivation, organization, coordination, monitoring and evaluation.

Developed countries to minimize the tax burden on small business for socio-economic development of the country.

Analysis of the existing realities, as well as the experience of different countries with good practices in addressing these issues, of course, can be useful. That is determined by the interest in the development of the social function of many developed welfare states: Such as the UK, Sweden, Denmark, Belgium, Germany, Japan, and other social function, which is focused only on individual civil responsibility for their own well-being, loses its unifying principle, neutralizing the solidarity and humanism. It is necessary to seek a compromise. All groups of the population who do not have, for whatever reason, the possibility to engage in employment, should have the opportunity to compulsorily meet their needs of public authorities, or under close supervision of the above. The populations concerned should be granted state aid and guarantees of social support. Naturally, the idea of the transformation of social functions is not mandatory prerogative of Russia at the present stage ofldevelop(in)ent - a global trend, which is caused by objectively. Nearly all states in which social development areas, actively embarked on this kind of transformation is still in the 80-90-ies. XX century. That Russia is forced to go on a new path of development of social functions.

The Russian government and Russian President paying close attention to the development and modification of the social function of taxes. Joined many programs on social support of the population, such as: The federal program for increasing the birth rate, the Federal program "Family to every child", but on the other hand, introduced and "monetization of benefits", which can be considered a way of modifying the provision of certain groups of social assistance to the population. Established the basic principles of social law state regarding scheduled, and in some areas have already started reforms in education, health, science, culture, when taken to its logical end the policy of commercialization of these areas call into question the constitutional rights of Russian citizens. You can, of course, deplore the fact that the social function of the state, expanding, changing the way of its realization can be resent in public, using the situation for the acquisition of a certain support in the political struggle, but the real problem of the social function of taxes in Russia today remain. On taxes debated at meetings of parliaments and parties, promising to reduce them (during election campaigns), and then raise them between elections. Taxes, being one of the main methods of economic regulation, are used to suppress the unfavorable economic trends, and to promote changes in the right direction for the development of society. If the tax system is fair, it can not ignore the fact that the taxpayers-businesses have different abilities to pay taxes - whether they are large or small - and they can not be equated.

The idea of fairness in taxation and is expressed in the justification of the need for a minimum income, which would be free of tax. Negatively affect the implementation of paid services everywhere, both in education and in other spheres of social character, the mood of the population. Quality manifestation taking place and planned processes in the social sphere of the economy and the general public is a top priority. According to the man in the street, now a social justice is available only to a narrow circle of persons who have the power. When implemented changes in tax legislation, the abolition of tax relief is no longer valid state support for socially vulnerable citizens due to the formation of a chronic budget deficit, which does not allow to fully implement support for citizens - therefore no desire to pay taxes. As a result of the general decline in living standards, an exacerbation of social and physical problems in a society is an increase in the proportion of people dissatisfied with the policy of the state. Withdrawing from organizations a considerable part of the money earned by them, the government slows down their expansion and development. The organization is not able to form the foundations of accumulation and consumption, and thereby lost the possibility of formation of sources of social and economic development of the employees and the organization as a whole. The economic behavior of the population depends on social justice. If there is no confidence in the fairness of the social system, there will be no activity at 
work. Often it clashes with injustice in the field of taxes generate irresponsibility and a passive attitude to the situation in the country as a whole.

\section{REFERENCES}

[1] Fedeal tax service of Russia. URL: https://www.nalog.ru/eng/1.html

[2] Doing business (Rate). URL: http://russian.doingbusiness.org/
[3] Russia income taxes and tax laws. URL: http://www.worldwidetax.com/russia/russia_tax.asp

[4] Russia Personal income tax rate. URL: http://www.tradingeconomics.com/russia/personal-income-tax-rate

[5] Deloitte "Doing business in Russia 2015". URL: https://www2.deloitte.com/content/dam/Deloitte/ru/Documents/tax/doin g-business-in-Russia-2015.pdf 